\title{
Gamma Ray Induced Radio Sensitivity in Three Different Mulberry (Morus) Genotypes
}

\author{
Hyadalu Lingappa Ramesh ${ }^{1}$, Veerapura Narayanappa Yogananda Murthy ${ }^{2 *}$, Munirajappa ${ }^{3}$ \\ ${ }^{1}$ Department of Sericulture, V. V. Pura College of Science, Bangalore, India; ${ }^{2}$ Department of Life Sciences, Ganga Kaveri Institute of \\ Science and Management, Bangalore, India; ${ }^{3}$ Department of Sericulture/Life Sciences, Jnana Bharathi Campus, Bangalore University, \\ Bangalore, India. \\ Email: *yoga16@rediffmail.com
}

Received April $9^{\text {th }}, 2013$; revised May $9^{\text {th }}, 2013$; accepted June $1^{\text {st }}, 2013$

Copyright (c) 2013 Hyadalu Lingappa Ramesh et al. This is an open access article distributed under the Creative Commons Attribution License, which permits unrestricted use, distribution, and reproduction in any medium, provided the original work is properly cited.

\begin{abstract}
Mulberry genotypes $\mathrm{M}_{5}, \mathrm{~S}_{54}$ and Kosen were procured from mulberry germplasm bank, Department of Sericulture, Bangalore University. Juvenile twigs of mulberry genotypes were used for cuttings preparation. Newly prepared juvenile cuttings were irradiated with different doses of gamma rays $(1 \mathrm{kR}-10 \mathrm{kR})$ from $\mathrm{Co}^{60}$ gamma unit. Propagation parameters like sprouting, rooting, survivability, plant height, number of branches, internodal distance and leaf area were recorded. Results revealed decline in growth parameters with the increase in gamma ray dosage (1 kR - $10 \mathrm{kR})$. Moderate dosages ( $4 \mathrm{kR}-7 \mathrm{kR})$ are the most competent range and height of the irradiated population significantly reduced with the increase in gamma rays dosage. Higher doses of gamma rays (8 kR - $10 \mathrm{kR})$ drastically reduced the number of branches. $\mathrm{M}_{5}$ and $\mathrm{S}_{54}$ showed marked improvement in plant height at $4 \mathrm{kR}(155.14 \mathrm{~cm})$ and $7 \mathrm{kR}(147.86$ cms) respectively compared to control. Morphologically, leaf mutants like enlarged (4 kR), curled (8 kR), mosaic (8kR) and biforked ( $9 \mathrm{kR}$ ) leaves were observed in gamma irradiated $\mathrm{M}_{5}$ genotype. Kosen exhibited small, crumpled, biforked and chlorophyll deficient leaves (8 kR - $10 \mathrm{kR})$. $\mathrm{S}_{54}$ exhibited boat shaped leaves with wrinkled texture (8 kR).
\end{abstract}

Keywords: $\mathrm{M}_{5}$; $\mathrm{S}_{54}$; Kosen; Gamma; Sprouting; Rooting; Survivability; Plant Height; Leaf Area

\section{Introduction}

Mulberry is a vegetatively propagated crop and is sensitive to gamma irradiation. Mulberry constitutes the only food plant of silkworm Bombyx mori L. Although different mulberry genotypes are available in nature, all are not utilized for silkworm rearing due to lack of one or the other important morphological trait. Karnataka state has complex agro-climatic zones and enjoys tropical climatic condition congenial for rearing silkworm throughout the year. Successful exploitation of various mutagenic agents for inducing aberration has become one of the most important lines of contemporary research. Gamma ray has been proved to be highly potent in inducing variability in mulberry plant [1-4]. Mutation breeding in mulberry has contributed to crop improvement world-wide and has made substantial impact on the productivity and economic value of the crop. Mutation induction in mulberry started towards the end of 1950's in Japan [5]. Mutagens have revolutionized the mulberry and silk production

\footnotetext{
"Corresponding author.
}

across the world and gamma ray has the potency to induce variability even at low frequencies [6]. Present investigation aims at improving the morpho-economic traits with higher yield and nutritionally superior leaves of different mulberry genotypes by using gamma irradiation.

\section{Materials and Methods}

In the present investigation, mulberry genotypes $M_{5}, S_{54}$ and Kosen were procured from mulberry germplasm bank maintained by Department of Sericulture at Jnana Bharathi Campus, Bangalore University, Bangalore. Juvenile twigs of mulberry genotypes were used for cuttings preparation and only middle part of the twigs were taken. Each cutting measured about $15 \mathrm{cms}$ in length having 2 - 3 active vegetative buds, free from pathogen and pests were prepared. Care was taken to avoid damage to the buds and cut ends while preparing cuttings. Newly prepared juvenile cuttings were irradiated with different doses of gamma rays $(1 \mathrm{kR}-10 \mathrm{kR})$ from $\mathrm{Co}^{60}$ gamma unit installed at the Indian Institute of Horticul- 
ture Research (IIHR), Hesaraghatta, Bangalore-560088. Irradiation was conducted during summer months and ten replications were maintained for the calculation of mean values of all the parameters encountered. Irradiated cuttings were planted in earthen pots filled with a mixture of well dried pulverized garden soil, fine sand and well decomposed farmyard manure in the proportion of 1:1:1. Three replications having ten cuttings each were maintained for six months before transplanting them in to the main field. Pots were arranged in rows giving a spacing of $1 / 2$ feet between pots and 1 foot between rows. Transplanted twigs were planted in randomized block design with $90 \mathrm{~cm} \times 90 \mathrm{~cm}$ spacing. Necessary cultural operations such as timely irrigation, weeding, inter cultivation, manuring, protection against desiccation, diseases and pests were ensured. Suitable controls were also maintained in similar conditions for comparative studies. At $\mathrm{M}_{1}$ and $\mathrm{M}_{2}$ generations, data related to growth responses such as sprouting, rooting, survivability, internodal distance, branching pattern and leaf area were recorded according to the methods suggested by [7-9]. Data collected on various parameters in the present investigation were tabulated using "Method of Analysis of Variance" appropriate to the experiment design $[10,11]$.

\section{Results and Discussion}

Linear decrease in sprouting percentage was observed in all the selected mulberry genotypes for irradiation. Radiation sensitivity in $\mathrm{M}_{5}$ genotype was noticed highest sprouting percentage at $1 \mathrm{kR}(81.30 \%)$ and least at $10 \mathrm{kR}$ (21.50\%) when compared to control (92.40\%). Kosen exhibited decreased trend in sprouting with increase in gamma ray dosage. Sprouting percentage was highest at $1 \mathrm{kR}(83.66 \%)$ and least at $10 \mathrm{kR}(18.66 \%)$ compared to control (85.66\%). In control plants sprouting were noticed on 8th day of planting and delayed sprouting was observed when cuttings were irradiated at $1 \mathrm{kR}$ to $5 \mathrm{kR}$ gamma rays and taken 13 - 15 days to sprout. In $\mathrm{S}_{54}$ genotype, maximum sprouting percentage recorded at 1 $\mathrm{kR}(78.49 \%)$ and minimum at $8 \mathrm{kR}(36.28 \%)$ and deformed inflorescence noticed at $7 \mathrm{kR}$ (Figure 1). $\mathrm{S}_{54}$ genotype showed decreased sprouting with the increase in gamma ray dosage and ranged between $78.49 \%(1 \mathrm{kR})$ to $36.28 \%$ (8 kR) and sprouting was not observed in 10 $k R M_{5}$ genotype cuttings showed varied rooting percentages and gradual reduction in rooting percentage was observed in $1 \mathrm{kR}(83.70 \%), 2 \mathrm{kR}(81.40 \%), 3 \mathrm{kR}$ (74.50\%) and drastic reduction was noticed at $9 \mathrm{kR}$ (34.40\%) and $10 \mathrm{kR}(32.20 \%) . \mathrm{M}_{5}$ cuttings irradiated at 4 kR exhibited more number of roots (Figure 2) and higher rooting (90.30\%) compared to control (89.20\%). Control plants of $\mathrm{S}_{54}$ genotype showed $88.33 \%$ of rooting. Cuttings of $\mathrm{S}_{54}$ taxon exhibited varied responses to different doses of gamma rays. Rooting percentage was decreased

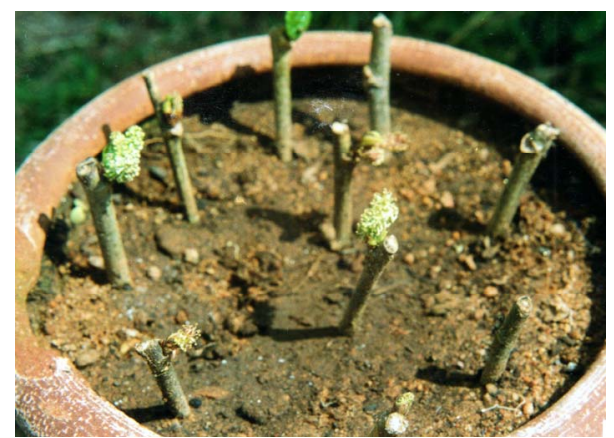

Figure 1. $\mathrm{S}_{54}$ mulberry genotype cuttings irradiated at $7 \mathrm{kR}$ gamma irradiation exhibiting deformed inflorescence.

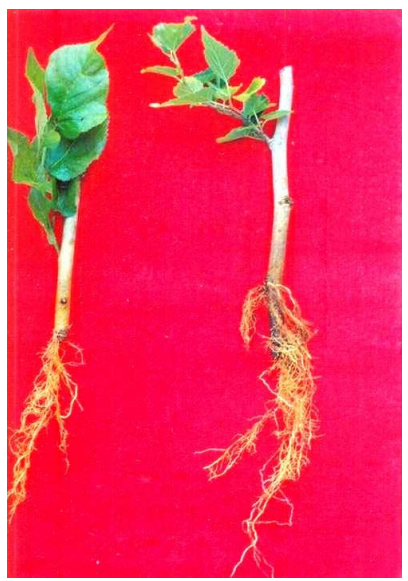

Figure 2. $M_{5}$ mulberry genotype mutants irradiated at $4 \mathrm{kR}$ exhibited good rooting compared to control.

from $1 \mathrm{kR}$ to $9 \mathrm{kR}$ except at $7 \mathrm{kR}$ (81.33\%) and at $10 \mathrm{kR}$, root initiation was not noticed. Among the irradiated cuttings of Kosen, highest rooting was noticed at $2 \mathrm{kR}$ (78.06\%) and least at $9 \mathrm{kR}(13.76 \%)$ and control cuttings showed $81.70 \%$ rooting (Tables 1-3). Present results are in conformity with the findings of many scientists $[4,12$, 13]. Moisture and agro-climatic conditions are the binding factors which influence sprouting [14]. Gamma rays are more potent and highly penetrating, might have developed cells that were undergoing meiotic division in the bud-region $[6,13]$. Sprouting percentage decreased with increase in gamma ray dosage and it was mainly due to partial cell death [3]. Significant reduction in rooting was found with the increase in gamma rays dosage. Higher the dosage of gamma rays, lesser the rooting and root proliferation. Rooting behaviour of a variety is purely a genetic character [15]. Relatively low percentage of rooting (50\%) was observed in mutant strains of Ichinose over its control and mutant of KNG produced low percentage of rooting (16\% - 32\%), whereas normal KNG variety showed $96 \%$ of rooting [16].

Survivability percentage in $\mathrm{M}_{5}$ mulberry genotype showed continuously declining trends. $\mathrm{LD}_{50}$ of $\mathrm{M}_{5}$ was found between $6 \mathrm{kR}(61.20 \%)$ and $7 \mathrm{kR}(52.30 \%)$, while 
Table 1. Effect of gamma irradiation on propagation and growth attributes of $\mathbf{M}_{5}$ mulberry genotype at $\mathbf{M}_{1}$ generation.

\begin{tabular}{|c|c|c|c|c|c|c|c|}
\hline Treatment & Sprouting \% & Rooting \% & Survival \% & $\begin{array}{l}\text { Plant height } \\
\quad(\mathrm{cm})\end{array}$ & $\begin{array}{c}\text { Number of } \\
\text { branches (no.) }\end{array}$ & $\begin{array}{c}\text { Internodal } \\
\text { distance }(\mathrm{cm})\end{array}$ & Leaf area $\left(\mathrm{cm}^{2}\right)$ \\
\hline Control & 92.40 & 89.20 & 87.70 & 142.23 & 6.14 & 4.29 & 167.28 \\
\hline $1 \mathrm{kR}$ & 81.30 & 83.70 & 85.40 & 135.29 & 5.98 & 4.31 & 169.14 \\
\hline $2 \mathrm{kR}$ & 78.70 & 81.40 & 79.28 & 131.11 & 6.01 & 4.38 & 168.28 \\
\hline $3 \mathrm{kR}$ & 69.20 & 74.50 & 84.40 & 125.94 & 5.91 & 4.33 & 151.43 \\
\hline $4 \mathrm{kR}$ & 76.40 & 90.03 & 71.80 & 155.14 & 6.95 & 4.01 & 174.45 \\
\hline $5 \mathrm{kR}$ & 71.80 & 64.30 & 64.40 & 117.24 & 5.74 & 4.52 & 139.18 \\
\hline $6 \mathrm{kR}$ & 52.90 & 49.40 & 61.20 & 104.29 & 5.68 & 4.07 & 123.24 \\
\hline $7 \mathrm{kR}$ & 41.40 & 43.90 & 52.30 & 96.78 & 4.69 & 4.11 & 116.11 \\
\hline $8 \mathrm{kR}$ & 44.20 & 37.50 & 49.40 & 89.59 & 4.81 & 4.41 & 121.18 \\
\hline $9 \mathrm{kR}$ & 29.40 & 34.40 & 39.20 & 66.23 & 4.14 & 4.39 & 112.18 \\
\hline $10 \mathrm{kR}$ & 21.50 & 32.20 & 29.70 & 54.29 & 4.07 & 4.59 & 98.70 \\
\hline SEM & - & 0.98 & - & 4.29 & 0.91 & 0.48 & 4.78 \\
\hline $\mathrm{CD}$ at $5 \%$ & NS & 1.62 & NS & 6.21 & 1.08 & 0.79 & 6.59 \\
\hline
\end{tabular}

NS: Non-significant.

Table 2. Effect of gamma irradiation on propagation and growth attributes of Kosen mulberry genotype at $\mathrm{M}_{1}$ generation.

\begin{tabular}{|c|c|c|c|c|c|c|c|}
\hline Treatment & Sprouting \% & Rooting \% & Survival \% & $\begin{array}{l}\text { Plant Height } \\
\text { (cm) }\end{array}$ & $\begin{array}{c}\text { Number of } \\
\text { branches (no.) }\end{array}$ & $\begin{array}{c}\text { Internodal } \\
\text { distance }(\mathrm{cm})\end{array}$ & Leaf area $\left(\mathrm{cm}^{2}\right)$ \\
\hline Control & 85.66 & 81.70 & 86.90 & 123.83 & 7.60 & 4.35 & 79.36 \\
\hline $1 \mathrm{kR}$ & 83.66 & 77.96 & 78.70 & 105.00 & 7.73 & 3.76 & 86.63 \\
\hline $2 \mathrm{kR}$ & 82.33 & 78.06 & 74.90 & 96.29 & 5.86 & 4.17 & 70.80 \\
\hline $3 \mathrm{kR}$ & 65.66 & 69.96 & 72.30 & 88.00 & 5.10 & 4.06 & 72.33 \\
\hline $4 \mathrm{kR}$ & 70.33 & 51.36 & 69.50 & 77.56 & 5.13 & 2.94 & 56.63 \\
\hline $5 \mathrm{kR}$ & 56.66 & 59.60 & 51.70 & 95.90 & 5.33 & 4.13 & 72.03 \\
\hline $6 \mathrm{kR}$ & 50.33 & 28.10 & 32.70 & 68.03 & 4.60 & 4.73 & 66.46 \\
\hline $7 \mathrm{kR}$ & 46.00 & 34.90 & 37.80 & 52.20 & 3.60 & 4.74 & 45.00 \\
\hline $8 \mathrm{kR}$ & 46.66 & 19.83 & 26.20 & 63.16 & 4.00 & 4.16 & 61.80 \\
\hline $9 \mathrm{kR}$ & 22.33 & 13.76 & 21.30 & 52.13 & 3.80 & 3.98 & 53.46 \\
\hline $10 \mathrm{kR}$ & 18.66 & 19.59 & 24.50 & 58.03 & 4.23 & 3.94 & 45.53 \\
\hline SEM & - & - & - & - & 0.23 & 0.07 & 1.07 \\
\hline $\mathrm{CD}$ at $5 \%$ & NS & NS & NS & NS & 1.28 & 1.82 & 2.21 \\
\hline
\end{tabular}

NS: Non-significant. 
Table 3. Effect of gamma irradiation on propagation and growth attributes of $S_{54}$ mulberry genotype at $M_{1}$ generation.

\begin{tabular}{|c|c|c|c|c|c|c|c|}
\hline Treatment & Sprouting \% & Rooting \% & Survival \% & $\begin{array}{l}\text { Plant Height } \\
\text { (cm) }\end{array}$ & $\begin{array}{c}\text { Number of } \\
\text { branches (no.) }\end{array}$ & $\begin{array}{c}\text { Internodal } \\
\text { distance }(\mathrm{cm})\end{array}$ & Leaf area $\left(\mathrm{cm}^{2}\right)$ \\
\hline Control & 92.48 & 88.33 & 88.00 & 138.98 & 5.88 & 3.81 & 144.26 \\
\hline $1 \mathrm{kR}$ & 78.49 & 81.27 & 81.49 & 131.14 & 6.01 & 3.85 & 129.31 \\
\hline $2 \mathrm{kR}$ & 72.19 & 79.10 & 79.48 & 128.78 & 6.14 & 2.75 & 134.27 \\
\hline $3 \mathrm{kR}$ & 67.20 & 73.14 & 68.17 & 114.57 & 5.78 & 3.98 & 131.13 \\
\hline $4 \mathrm{kR}$ & 53.18 & 61.18 & 54.33 & 101.68 & 5.97 & 3.78 & 128.29 \\
\hline $5 \mathrm{kR}$ & 49.28 & 59.78 & 47.08 & 94.18 & 6.18 & 3.81 & 101.01 \\
\hline $6 \mathrm{kR}$ & 51.06 & 51.39 & 49.98 & 88.68 & 6.73 & 3.68 & 98.47 \\
\hline $7 \mathrm{kR}$ & 44.19 & 81.33 & 40.30 & 147.86 & 6.71 & 2.99 & 146.22 \\
\hline $8 \mathrm{kR}$ & 36.28 & 42.78 & 35.18 & 34.18 & 4.16 & 2.87 & 82.29 \\
\hline $9 \mathrm{kR}$ & 38.24 & 29.16 & 38.24 & 33.32 & 4.09 & 2.80 & 72.67 \\
\hline $10 \mathrm{kR}$ & - & - & - & - & - & - & - \\
\hline SEM & - & - & - & 2.48 & 0.86 & 0.47 & 7.29 \\
\hline CD at $5 \%$ & NS & NS & NS & 3.57 & 1.91 & 1.01 & 8.76 \\
\hline
\end{tabular}

NS: Non-significant.

acute doses like $9 \mathrm{kR}$ (39.20\%) and $10 \mathrm{kR}$ (29.70\%) proved to be lethal for the taxa studied. In Kosen, survivability percentage was maximum at $1 \mathrm{kR}(78.70 \%)$ and minimum at $9 \mathrm{kR}(21.30 \%)$ and control plants showed $86.90 \%$. $\mathrm{S}_{54}$ genotype showed stunted growth, weak and feeble branches at $8 \mathrm{kR}$ and $9 \mathrm{kR}$ and survival percentage was maximum at $1 \mathrm{kR}(81.49 \%)$ and minimum at $8 \mathrm{kR}$ (35.18\%) and control plants recorded $88.00 \%$ of survivability (Tables 1-3). Survivability percentage varied depending upon dosage of gamma rays administered. Present findings are in confirmation with the results of many other workers $[12,17,18]$. They have concluded that, low doses of gamma irradiation could be used as safe and effective tools to induce variations towards improving mulberry cultivars and increased dosages of gamma rays ( $9 \mathrm{kR}$ and $10 \mathrm{kR}$ ) produced semi lethality to complete lethality. Decrease in survival percentage after radiation treatment was attributed to the destruction of auxins $[19,20]$. Survivability in mulberry varieties $S_{30}$ and $K_{2}$ and revealed that, the injury was directly proportional to concentration of mutagen and also disturbances caused at the physico-chemical level in cells or acute chromosomal damage or due to combined effect of both. Decrease in the survivability of irradiated plant material to the series of events occurring at the cellular level which affect the vital macromolecules and result in physiological imbalance [21]. Survivability indicates the capacity of treated population to withstand even the severe dosage of gamma rays [22]. Survival percentage in the entire irradiated mulberry varieties showed a continuously decreasing trend. Sensitivity of the plant material depends on the genetic constitution, dose employed, DNA amount, its replication time at initial stages, moisture content, stage of development and genotype [6].

Height of the irradiated population of $\mathrm{M}_{5}$ considerably reduced when increased gamma ray dosage is administered. Appreciable increase in plant height was noticed at $4 \mathrm{kR}(155.14 \mathrm{~cm})$ when compared to control $(142.23 \mathrm{~cm})$. Kosen also exhibited the same trend and declining plant height with increase in gamma ray dosage and recorded highest at $1 \mathrm{kR}(105.00 \mathrm{~cm})$ and least at $9 \mathrm{kR}(52.13 \mathrm{~cm})$ compared to control $(123.83 \mathrm{~cm})$. Plants height in treated populations of $\mathrm{S}_{54}$ ranged from $147.86 \mathrm{~cm}(7 \mathrm{kR})$ to $33.32 \mathrm{~cm}(9 \mathrm{kR})$ compared to control $(139.98 \mathrm{~cm})$. At 10 kR though the irradiated cuttings sprouted initially, they did not grow further. Branches considerably increased at 4 kR (6.95) (Figure 3) in $\mathrm{M}_{5}$ genotype and drastically reduction in number of branches noticed between the range $8 \mathrm{kR}$ (4.81) - $10 \mathrm{kR}$ (4.07), where irradiated progenies showed semi lethality to complete lethality. Kosen genotype showed maximum branches at $1 \mathrm{kR}$ (7.73) and 


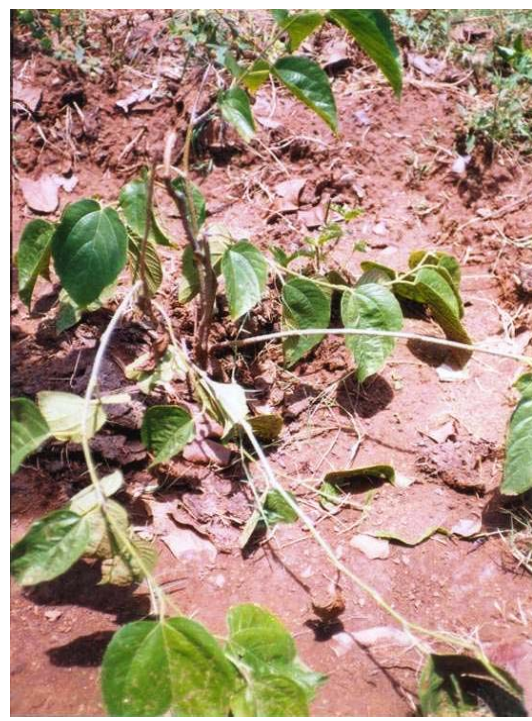

Figure 3. $M_{5}$ mulberry genotype mutants irradiated at $4 \mathrm{kR}$ exhibited increased tendency in the number of branches.

decreased number of branches was noticed at $9 \mathrm{kR}$ (3.80) and $10 \mathrm{kR}$ (4.23). Increased dosage of gamma ray irradiation lowered the formation of new shoots. $\mathrm{S}_{54}$ genotype also exhibited varied branching patterns and maximum branching was observed at $6 \mathrm{kR}$ (6.73) and $7 \mathrm{kR}$ (6.71) and lowest number of branches were recorded at 9 $\mathrm{kR}$ (4.09). Internodal distance of $\mathrm{M}_{5}$ genotype recovered from gamma irradiated cuttings showed reduced intermodal distance at $4 \mathrm{kR}(4.01 \mathrm{~cm}), 6 \mathrm{kR}(4.07 \mathrm{~cm})$ and 7 $\mathrm{kR}(4.11 \mathrm{~cm})$ and at lower doses $1 \mathrm{kR}(4.31)$ to $3 \mathrm{kR}$ (4.33) this trait was not affected. Internodal distance in Kosen did not show much variation in all the treated population except at $4 \mathrm{kR}(2.94 \mathrm{~cm})$ compare to control $(4.35 \mathrm{~cm})$. In $\mathrm{S}_{54}$ genotype, higher dosage of gamma ray (7 kR - $9 \mathrm{kR}$ ) indicated decreased internodal distance which ranged from $2.99 \mathrm{~cm} 2.80 \mathrm{~cm}$. Least internodal distance was observed at $2 \mathrm{kR}(2.75 \mathrm{~cm})$ compared to control $(3.81 \mathrm{~cm})$. Leaf area is a desirable morpho-economic trait in mulberry and was considerably decreased due to gamma irradiation in $\mathrm{M}_{5}$ genotype. Plants irradiated with $1 \mathrm{kR}$ gamma rays showed slightly bigger leaves $\left(169.14 \mathrm{~cm}^{2}\right)$ compared to control $\left(167.28 \mathrm{~cm}^{2}\right)$ and small leaves were observed at $10 \mathrm{kR}\left(98.70 \mathrm{~cm}^{2}\right)$. Irradiated populations of Kosen showed maximum leaf area at $1 \mathrm{kR}$ $\left(86.63 \mathrm{~cm}^{2}\right)$ and minimum at $7 \mathrm{kR}\left(45.00 \mathrm{~cm}^{2}\right)$ compared to control $\left(79.36 \mathrm{~cm}^{2}\right)$. Irradiated population at $8 \mathrm{kR}, 9$ $\mathrm{kR}$ and $10 \mathrm{kR}$ exhibited small, crumpled, biforked and chlorophyll deficient leaves (Figures 4, 5). In $\mathrm{S}_{54}$ mulberry genotype enlarged leaf area was observed in the populations irradiated at $1 \mathrm{kR}\left(129.31 \mathrm{~cm}^{2}\right), 2 \mathrm{kR}$ $\left(134.27 \mathrm{~cm}^{2}\right)$ and $4 \mathrm{kR}\left(128.29 \mathrm{~cm}^{2}\right)$ gamma rays. $7 \mathrm{kR}$ $\left(146.22 \mathrm{~cm}^{2}\right)$ exhibited largest leaf area and least at $9 \mathrm{kR}$ (72.67 $\left.\mathrm{cm}^{2}\right)$ when compared to control $\left(144.26 \mathrm{~cm}^{2}\right)$. Boat shaped, wrinkled, curly and chlorophyll deficient

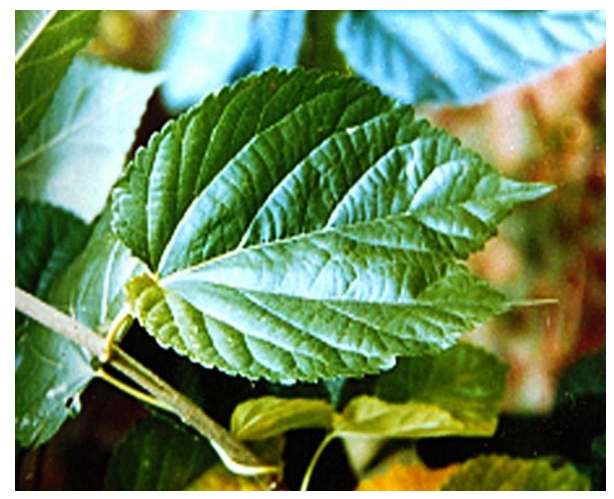

Figure 4. Kosen mulberry genotype mutants irradiated at 8 kR gamma irradiation showing biforked leaves.

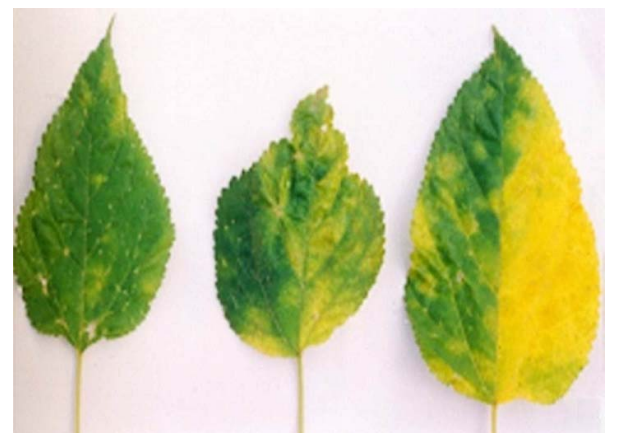

Figure 5. Kosen mulberry genotype mutants irradiated at 8 kR gamma irradiation showing chlorophyll deficient leaves.

leaves were observed in the population with $8 \mathrm{kR}$ and 9 kR (Figures 6-8; Tables 1-3).

Mulberry is a polygenic plant. Plant height is a quantitative trait which is predominantly controlled by polygene. Each gene contributes small effects called genetic addictive effect [23]. In some cases mutation are not stable, they will undergo recombination during meiosis [24]. Multicellular organisms have the ability to recover from sub lethal doses of ionizing radiations. Even with in a cell, non-damaged molecule may be able to take over metabolic process and exerts a gradual recovery to normal levels [25]. Efficiency of selecting the desired mutant is controlled by single gene [26]. Generally if the doses are too high, many plants get killed, because physical mutagens can have direct negative effects on plant tissue and many mutations can be lethal. This is due to the fact that, primary injuries are retardation or inhibition of cell division. Cell death affects the growth habit and changes in plant morphology. These effects are due to cytological changes such as chromosomal damages, inhibited mitotic division, degeneration of nuclei, cell enlargement etc., have been reported by many scientists [27-31]. If the dose is too low, there will not be enough mutation because of low mutation frequency and it results in small mutated sector. Branching pattern is controlled by polygenes and mutations are not stable and 


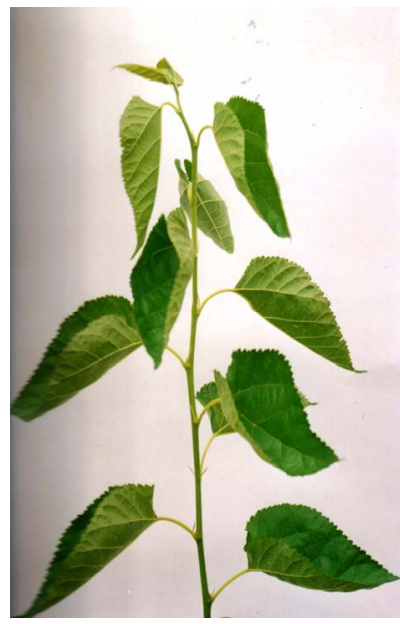

Figure 6. $\mathrm{S}_{54}$ mulberry genotype mutant recovered at $8 \mathrm{kR}$ gamma irradiation showing boat shaped leaves.

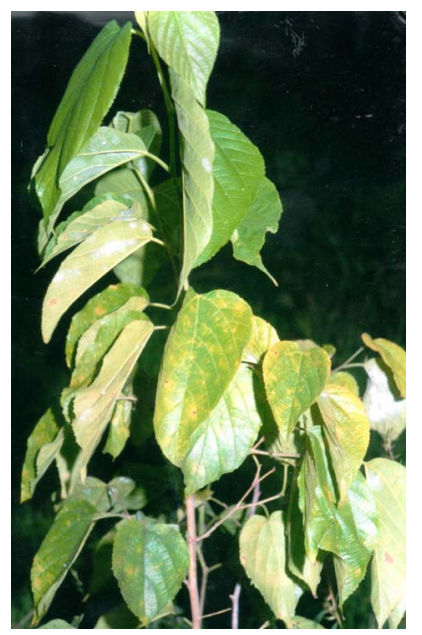

Figure 7. $\mathrm{S}_{54}$ mulberry genotype mutant recovered at $9 \mathrm{kR}$ gamma irradiation showing wrinkled texture leaves.

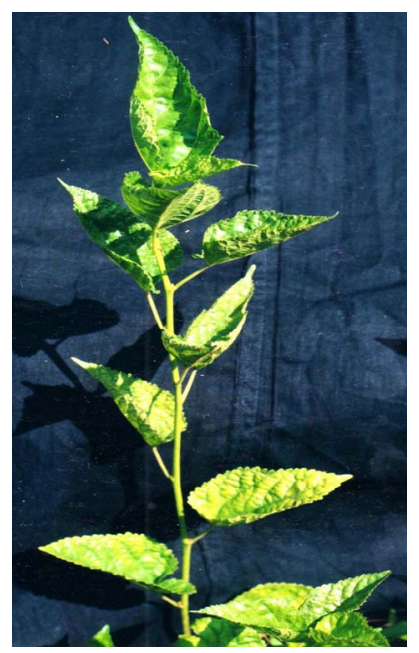

Figure 8. $\mathrm{S}_{54}$ mulberry genotype mutant recovered at $9 \mathrm{kR}$ gamma irradiation exhibiting and curled and chlorophyll deficient leaves. vary with mutagenic sensitivity. Radio sensitivity and bud mutation of mulberry in gamma irradiated population showed deformations like inhibition of height and branching pattern [24,32-34]. Intermodal distance was found to be affected by cell number and cell length or both in barley [35]. Similar observations namely shortened internodes in the mutants of Mysore local mulberry variety treated by gamma irradiation has been reported [12]. Mulberry is a cross pollinated heterozygous plant induced mutations create new genetic variations in leaf area at different doses. Similar findings affecting leaf area, shape and size have been reported in large number of genotypes from time to time through irradiation by several investigators [3,32,36,37]. Several leaf mutants viz., venosa, wrinkled leaf, glossy leaves etc., in case of spontaneous mutants of mulberry have registered [38]. Abnormalities in leaves are due to disturbances by phytochromes, chromosomal aberrations and mitotic inhibition [39-41]. Gamma rays administered in the present investigation marginally affected the reproductive parts and inflorescence length at maturity.

Three mulberry genotypes were subjected to different doses of gamma irradiation ( $1 \mathrm{kR}-10 \mathrm{kR})$ and various morphological and growth parameters were recorded. It is commonly observed in the genotypes that, with the increase in gamma ray dosage, there was linear decrease in the performance of various growth parameters viz., sprouting, rooting, survivability, plant height and leaf area were not of much promising nature. Gamma ray is a potent physical mutagen which could induce variability in all three mulberry genotypes. In the present investigation, promising mutants were identified in $\mathrm{M}_{5}$ genotype at $4 \mathrm{kR}$. In Kosen, no remarkable variation observed in treated population and only leaf abnormalities such as biforked and chlorophyll deficiency was observed. Plants height was drastically reduced at higher doses (7 kR - 10 $\mathrm{kR}$ ) of irradiation. Mulberry genotype $\mathrm{S}_{54}$ showed appreciable increase in plant height at $7 \mathrm{kR}$. This is only a preliminary investigation and the mutants showing beneficial traits are to be grown for $\mathrm{M}_{2}$ and $\mathrm{M}_{3}$ generation to confirm the superiority of the race.

\section{REFERENCES}

[1] I. Tojyo, "Studies on Polyploidy Mulberry Tree I. Breeding of Artificial Autotetraploids," Bulletin of the National Science Museum (Japan), Vol. 20, No. 3, 1966, pp. 187207.

[2] K. Hazama, "Induced Mutations and Plant Breeding Methods in Vegetatively Propagated Species,” The Journal of Sericultural Science of Japan, Vol. 36, No. 4, 1967, pp. 346-352.

[3] K. Katagiri, "Varietal Differences of Mutations Rate and Mutation Spectrum after Acute Gamma Ray Irradiation in Mulberry,” The Journal of Sericultural Science of Japan, 
Vol. 39, No. 3, 1970, pp. 194-200.

[4] A. Tikader, K. Vijayan, B. N. Roy and T. Pavankumar, "Studies on Propagation Efficiency of Mulberry [Morus spp.] at Ploidy Level,” Sericologia, Vol. 36, No. 2, 1996, pp. 345-349.

[5] T. Sugiyama and I. Tojyo, "Studies on the Effect of Irradiation on Bud of Mulberry Cutting in the Hybridization," Bulletin of the Sericultural Experiment Station, Vol. 18, No. 2, 1962, pp. 115-132.

[6] K. N. Deshpande, S. S. Mehetre and S. D. Pingle, "Effect of Different Mutagens for Induction of Mutations in Mulberry," Asian Journal of Experimental Biological Sciences, Vol. 1, 2010, pp. 104-108.

[7] S. B. Dandin and M. S. Jolly, "Mulberry Descriptor," Sericologia, Vol. 26, No. 4,1986, pp. 465-475.

[8] M. Sanjappa, "Geographic Distribution and Exploration of the Genus Morus L. (Moraceae),” In: K. Sengupta and S. B. Dandin, Eds., Genetic Resources of Mulberry and Utilization," Central Sericultural Research \& Training Institute, Mysore, 1989, pp. 4-7.

[9] Shamachary and M. S. Jolly, “A Simple Device for Quick Determination of Mulberry Leaf Area in the Field,” Indian Journal of Sericulture, Vol. 27, No. 1, 1988, pp. 51-54.

[10] G. L. Sundararaj, M. N. Nagaraju, Venkataramu and Jaganath, "Design and Analysis of Field Experiments," University of Agricultural Sciences, Miscellaneous Series No. 22, Bangalore, 1972, pp. 424- 440.

[11] R. K. Singh and B. D. Choudhury, "Biometrical Methods in Quantitative Genetic Analysis,” Kalyani Publishers, New Delhi, 1985.

[12] V. C. Jayaramaiah and Munirajappa, "Induction of Mutations in Mulberry Variety 'Mysore Local' by Gamma Irradiation,” Sericologia, Vol. 27, No. 2, 1987, pp. 199204.

[13] M. S. RaoEswar, S. B. Dandin, R. S. Mallikarjunappa, H. V. Venkateshaiah and U. D. Bongale, "Evaluation of Induced Tetraploid and Evolved Triploid Mulberry Genotypes for Propagation, Growth and Yield Parameters," Indian Journal of Sericulture, Vol. 43, No. 1, 2004, pp. 88-90.

[14] S. B. Dandin and R. Kumar, "Evaluation of Mulberry Genotypes for Different Growth and Yield Parameters," In: K. Sengupta and S. B. Dandin, Eds., Genetic Resources of Mulberry and Utilization, Central Sericultural Research \& Training Institute, Mysore, 1989, pp. 143151.

[15] H. T. Hartman and D. E. Kester, "Plant PropagationPrinciples and Practices,” Prentice Hall of India, 1976, pp. 120-135.

[16] H. Fujitha and M. Wada, "Studies on Mutation Breeding in Mulberry (Morus spp.)," In: Induced Mutations in Vegetatively Propagated Plants, IAEA, Vienna, 1982, pp. 249-279.

[17] K. Nakajima, "Induction of Useful Mutation in Mulberry by Gamma Irradiation,” Japan Agricultural Research Quarterly, Vol. 6, No. 4, 1972, pp. 195-198.

[18] B. C. Das, B. B. Bindroo, A. K. Tiku and R. K. Pandit,
"Propagation of Mulberry through Cuttings,” Indian Silk, Vol. 26, No. 1, 1987, pp. 12-13.

[19] F. Skoog, "The Effect of Radiation on Auxin and Plant Growth,” Journal of Cellular and Comparative Physiology, Vol. 7, 1935, pp. 227-270. doi:10.1002/jcp.1030070206

[20] G. F. Smith and H. Kersten, "Auxin in Seedlings from X-Rayed Seeds,” American Journal of Botany, Vol. 29, 1942, pp. 785-819. doi:10.2307/2437733

[21] C. R. Sastry, C. V. Venkataramu, A. Khan and J. V. Krishna Rao, "Chemical Mutagenesis for Productive Breeding in Mulberry," Seminar Organised in Commemoration of Silver Jubilee of Central Silk Board, 1974, p. 20.

[22] E. Gray, "Evidence of Phenotypic Plasticity in Mulberry (Morus L.)," Castanea, Vol. 55, 1990, pp. 272-281.

[23] T. L. Abdullah, S. Fakhrurazi and B. M. Nazir, "Changes in Flower Development, Chlorophyll Mutation and Alteration in Plant Morphology of Curcuma alismatifolia by Gamma Irradiation,” American Journal of Applied Sciences, Vol. 6, No. 7, 2009, pp. 1436-1439. doi:10.3844/ajassp.2009.1436.1439

[24] Anon, "Manual on Mutation Breeding," Technical Report Series, No. 119, IAEA, Vienna, 1977, pp. 169-192.

[25] M. J. Kearsey and H. S. Pooni, "The Genetic Analysis of Quantitative Traits,” Plant Genetic Group School of Biological Science, The University of Birmingham, Chapman and Hall, London, 1996, pp. 381-395.

[26] H. Brunner, "Methods of Induction of Mutations," Plant Breeding Unit, Joint FAO/IAEA Programme, IAEA Laboratories, Seibessdorf, 1995.

[27] A. H. Sparrow, M. J. Moses and R. J. Dubow, "Relationship between Ionizing Radiation in Plants," Conference on Radioactive Isotopes in Agriculture, East Housing Mich, AEG Rep. T.D, No. 7521, 1952, pp. 125-139.

[28] E. Pollard, "Ionizing Radiation: Effect on Genetic Transcription,” Science, Vol. 146, 1964, pp. 927-929. doi:10.1126/science.146.3646.927

[29] M. Maluszynski, "Mutation Techniques in Plant Breeding,” In: Induced Mutations and Molecular Techniques for Crop Improvement, Proceedings of a Symposium, IAEA and FAO, Vienna, 1995, pp. 489-504.

[30] R. R. Karpate and A. D. Choudhary, "Induced Mutation in Linumusitatissimum L.," Journal of Cytology and Genetics, Vol. 32, No. 1, 1997, pp. 41-48.

[31] M. B. Nazir, O. Mohamad, A. A. Affida and A. Sakinah, "Research Highlights on the Use of Induced Mutations for Plant Improvement in Malaysia,” Malaysian Institute for Nuclear Technology Research (MINT), Bangi, 1998.

[32] K. Hazama, “Adaptability of Mutant in Mulberry Tree,” Gamma Field Symposia, Vol. 7, 1968, pp. 79-85.

[33] K. Katagiri, "Polyploidy Induction in Mulberry by Gamma Radiations,” Mutation Breeding News Letter, Vol. 8, 1976, pp. 11-12.

[34] P. Rao, J. M. M. Rao and N. L. Sarojini, "Mutation Breeding in Mulberry Morus indica L.,” Indian Journal of Botany, Vol.7, No. 1, 1984, pp. 106-111. 
[35] A. D. Blonstein and M. D. Gale, "Cell Size and Cell Number in Dwarf Mutants of Barley in Semi Dwarf Cereal Mutants and Their Use in Cross Breeding. II (Teidsc 407),” FAO/IAEA, Vienna, 1984, pp. 19-29.

[36] U. Kuchkarov and K. U. Ogurtsov, "Spontaneous Mutants of Mulberry,” Shelk, Vol. 6, 1987, pp. 3-4.

[37] S. K. Datta and B. K. Banerji, “Gamma Ray Induced Somatic Mutation in Chrysanthemum c.v. 'Kalyani Mauve',” Journal of Nuclear Agriculture \& Biology, Vol. 22, No. 1, 1993, pp. 19-27.

[38] S. B. Dandin, M. V. Rajan and R. S. Mallikarjunappa, "Mutant Forms in Mulberry (Morus spp.)," Sericologia, Vol.36, No. 2, 1996, pp. 353-358.

[39] A. Abraham and C. A. Ninan, "Genetic Improvement of the Coconut Palm. Some Problems and Possibilities,” Indian Journal of Genetics and Plant Breeding, No. 28A, 1968, pp. 142-153.

[40] K. Mickaelsen, G. Ahnstrom and W. C. Li, "Genetic Effects of Alkylating Agent in Barley. Influence of PastStorage, Metabolic State and $\mathrm{pH}$ of Mutagen Solution," Heriditas, Vol. 59, 1968, pp. 353-374. doi:10.1111/j.1601-5223.1968.tb02183.x

[41] C. C. Moh, "The Use of Radiation Induced Mutations in Crop Breeding in Latin America and Some Biological Effects of Radiation in Coffee," The International Journal of Applied Radiation and Isotopes, Vol. 13, 1962, pp. 467-475. doi:10.1016/0020-708X(62)90021-2 